\title{
EFFECTS OF PH, TEMPERATURE AND LIGHT INTENSITY ON SPORE GERMINATION AND GROWTH ANALYSIS OF YOUNG SPOROPHYTES OF Polypodium lepidopteris (Pteridophyta, Polypodiaceae) ${ }^{1}$
}

\author{
Daniela Viviani² \& Áurea Maria Randi ${ }^{2,3}$
}

\begin{abstract}
(Effects of $\mathrm{pH}$, temperature and light intensity on spore germination and growth analysis of young sporophytes of Polypodium lepidopteris Kunze (Pteridophyta, Polypodiaceae)) Polypodium lepidopteris is a terrestrial fern from coastal vegetation, and is used as medicinal. This work analyzed the effects of $\mathrm{pH}$, temperature and light levels on the spore germination and the relative growth rate (RGR) of young sporophytes. Fertile fronds were collected in Florianópolis, SC, Brazil. The effect of $\mathrm{pH}$ (4.0 to 6.7) on spore germinability was observed in a growing room at $25 \pm 2^{\circ} \mathrm{C}\left(22 \mathrm{mmol} \mathrm{m}^{-2} \mathrm{~s}^{-1}\right)$ under a 16h photoperiod. No statistical differences between treatments were found. The effect of different temperatures on the germinability was analyzed $(20,25$ and $\left.30^{\circ} \mathrm{C}\right)$. The test was carried out in a germination chamber $\left(17 \mathrm{mmol} \mathrm{m}^{-2} \mathrm{~s}^{-1}\right)$ under a $16 \mathrm{~h}$ photoperiod. The germination was inhibited at $30^{\circ} \mathrm{C}$. The effect of natural light levels $(54,38,22$ and $8 \%)$ was analyzed. The highest germination percentages were verified at 22 and $8 \%$ of natural light. The growth analyses show statistical differences in the number of fronds and height of the longest frond between time 1 ( 283 days of spore inoculation) and time 2 ( 343 days of spore inoculation). Sporophytes of $P$. lepidopteris produced 1.33 \pm 0.09 fronds per month. The RGR (relative growth rate) was $0.15 \pm 0,009 \mathrm{~cm} \mathrm{~cm}^{-1} \mathrm{month}^{-1}$.
\end{abstract}

Key words: germination, growth, medicinal plant, Polypodium lepidopteris.

\section{Resumo}

(Efeito de $\mathrm{pH}$, temperatura e intensidade luminosa na germinação de esporos e análise de crescimento de esporófitos jovens de Polypodium lepidopteris Kunze (Pteridophyta, Polypodiaceae)) Polypodium lepidopteris é uma pteridófita terrestre que ocorre nas restingas e que apresenta propriedades medicinais. Este trabalho analisou o efeito de $\mathrm{pH}$, temperatura e níveis de luz na germinação de esporos e a taxa de crescimento relativo (TCR) de esporófitos jovens de P. lepidopteris. Frondes férteis foram coletadas em Florianópolis, SC, Brasil. O efeito do $\mathrm{pH}(4,0$ a 6,7$)$ na germinabilidade de esporos foi analisado em sala de cultivo a $25 \pm 2^{\circ} \mathrm{C}(22 \mathrm{mmol}$ $\left.\mathrm{m}^{-2} \mathrm{~s}^{-1}\right)$ sob fotoperíodo de 16 horas. Não houve diferença estatisticamente significativa entre os tratamentos. Diferentes temperaturas foram testadas $\left(20,25 \mathrm{e} 30^{\circ} \mathrm{C}\right)$ em câmara de germinação $\left(17 \mathrm{mmol} \mathrm{m}^{-2} \mathrm{~s}^{-1}\right)$ sob fotoperíodo de 16 horas. A germinação foi inibida a $30^{\circ} \mathrm{C}$. O efeito de diferentes níveis de luz natural $(54,38,22$ e $8 \%)$ foi analisado. As maiores porcentagens de germinação ocorreram a 22 e $8 \%$ de luz natural. A análise de crescimento dos esporófitos jovens mostra diferença significativa entre número de frondes e altura da maior fronde avaliados no tempo 1 (283 dias de inoculação de esporos) e no tempo 2 (343 dias de inoculação de esporos). Esporófitos de $P$. lepidopteris produziram 1,33 $\pm 0,09$ frondes por mês. A TCR (taxa de crescimento relativo) foi de $0,15 \pm 0,009 \mathrm{~cm} \mathrm{~cm}^{-1}$ mês.

Palavras-chave: germinação, crescimento, planta medicinal, Polypodium lepidopteris.

\section{INTRODUCTION}

Approximately $65 \%$ of the world fern species occur in the tropics (Tryon \& Tryon 1982). In Brazil, ferns occur preferentially in the Atlantic and Amazonian forests (Senna \& Kazmirczak 1997; Labiak \& Prado 1998) but some species are also found in the Brazilian caatinga, mangroves, coastal vegetation and pantanal (Tryon \& Tryon 1982; Barros et al. 1989; Ambrósio \& Barros 1997).

In the last few decades, several ornamental or medicinal ferns have been indiscriminately exploited. Polypodium lepidopteris (Langsd. \& Fisch.) Kunze (Polypodiaceae), a herbaceous and terrestrial species found in the Brazilian coastal vegetation called 'restinga' (CONAMA

Artigo recebido em 04/2008. Aceito para publicação em 10/2008.

${ }^{1}$ Part of the Msc thesis of Daniela Viviani (Programa de Pós-graduação em Biologia Vegetal, UFSC)

${ }^{2}$ Laboratório de Fisiologia Vegetal, Departamento de Botânica, Universidade Federal de Santa Catarina, 88040-900, Florianópolis/SC, Brasil.

${ }^{3}$ Autor para correspondência: amrandi@ccb.ufsc.br 
1999), is considered medicinal due to the presence of therapeutic substances. In order to establish immobile and half-fixed sanddunes, sporophytes of P. lepidoteris are small and have numerous trichomes and scales to reduce water loss and protect the epidermis from intense sunlight. The lamina of $P$. lepidopteris is more or less densely scaly and the stem scales are long and narrow (Tryon \& Tryon 1982).

Polypodium lepdopteris is used since 1924 in association with 'cainca' (Chiococca alba (L.) Hitchc, Rubiaceae) in a phytoterapic medicine form known as 'Rheumoflora ${ }^{\circledR}$ ', which had been initially manufactured by the 'Flora Medicinal' and is currently under the responsibility of 'Natura do Brasil'. This medicine is indicated as analgesic and antiinflammatory (Gazda et al. 2006). The whole plant presents therapeutically active principles, for this reason, whole plants or parts of the plants have been directly extracted from their habitat over many years.

There is a lack of information on fern germination and initial growth in literature. The knowledge of fern ecophysiology is of essential importance for the development of methods aimed at assisting their conservation and management.

The same exogenous factors needed for germination plus mineral nutrition are involved in growth and development of fern prothallus and in the formation of its sporophyte (Millër 1968; Pérez-García \& Riba 1982; Whittier \& Moyroud 1993; Fernández et al. 1996; Fernández et al. 1997; Ranal 1999; Nondorf et al. 2003).

This paper investigates the effect of $\mathrm{pH}$, light levels and temperature on the germination of Polypodium lepidopteris spores and analyzes the relative growth rate of sporophytes produced from the spore germination. The main objective was to contribute with ecophysiological information on germinability and young sporophyte growth, which could be useful to assist in management and conservation programmes.

\section{Material ANd Methods}

Sporophylls of Polypodium lepidopteris (Langsd. \& Fisch.) Kunze were collected in the 'Parque Municipal das Dunas da Lagoa da Conceição', east coast of the Santa Catarina Island, in the dunes of the Joaquina beach, Florianópolis,Brazil.

Sporophylls were dried at room temperature on filter paper in order to induce dehiscence. The spores were removed and separated from sporangia by filtering through lens paper and later stored in glass jars under refrigeration at $7 \pm 1^{\circ} \mathrm{C}$. Spores were surface sterilized in a $10 \%(\mathrm{v} / \mathrm{v})$ commercial bleach solution $(2 \%$ of active chlorine) for $20 \mathrm{~min}$ before filtering through sterile filter paper and washing several times with sterile distilled water. For the germination tests, about $10 \mathrm{mg}$ of the spores were sown in four conical flasks containing 20 $\mathrm{ml}$ of autoclaved liquid medium. The flasks were plugged with two layers of autoclaved transparent commercial polypropylene film (7 $\times 7 \mathrm{~cm}$ ) and fixed with rubber bands. Spores were inoculated in Mohr medium modified by Dyer (1979) supplemented with Benlate ${ }^{\circledast}$ (25 mg. $\left.\mathrm{L}^{-1}\right)$. The spore germination was carried out in growth room at $25 \pm 2^{\circ} \mathrm{C}\left(22 \mathrm{mmol} \mathrm{m}^{-2} \mathrm{~s}^{-}\right.$ ${ }^{1}$ ) under a 16-hour photoperiod. The $\mathrm{pH}$ of the mineral solutions was adjusted with $\mathrm{H}_{2} \mathrm{SO}_{4}$ to 4.0, 4.5, 5.0, 5.5, 6.0 and 6.7 (control). The percentage of germination was scored once a week and four slides from each treatment containing 100 spores each slide, were analyzed. The effect of 20,25 and $30^{\circ} \mathrm{C}$ on the germinability was analyzed and the test was carried out in a germination chamber $(17 \mathrm{mmol}$ $\mathrm{m}^{-2} \mathrm{~s}^{-1}$ ) under a $16-\mathrm{h}$ photoperiod.

To study the light level effects on spore germination, four Erlenmeyer flasks containing $20 \mathrm{ml}$ of autoclaved liquid medium were used per light treatment. Each flask was inoculated with surface sterilized spores $(10 \mathrm{mg})$ and kept in $50 \mathrm{~cm}^{3}$ boxes covered with black shade netting (sombrite) that provided 54, 38, 22 and $8 \%$ of natural light. A maximum and minimum thermometer was placed inside the boxes. Minimum and maximum temperatures were 
daily recorded at noon. Irradiance inside the boxes was also daily recorded, once a day, at noon. The irradiance levels were measured through a quantameter LICOR 250, using a PAR sensor (400 to $700 \mathrm{~nm}$ ). The boxes were kept outdoors, in a shade free open area.

After one month of cultivation in mineral solution, the spores developed into young filamentous gametophytes that were transferred to trays containing the following substrate: a) washed sand b) a mixture of sand, humus compost Aduplan ${ }^{\circledR}$ and typic hapludult soil in the proportion of $1: 1: 1$. The substrates were previously autoclaved for $60 \mathrm{~min}$ at $120^{\circ} \mathrm{C}$ in order to avoid contamination with spores from other fern species. The trays were kept in a growth room, at $25 \pm 2^{\circ} \mathrm{C}\left(22 \mathrm{mmol} \mathrm{m}^{-2} \mathrm{~s}^{-1}\right)$, under a 16-hour photoperiod for sporophyte production. For growth analysis, 30 sporophytes ( $\mathrm{ca} 4 \mathrm{~cm}$ tall) were transplanted individually for small vases $(125 \mathrm{ml})$, which were kept in transparent polyethylene boxes (San Remo ${ }^{\circledR}, 28.2 \mathrm{~L}$ ). The number of sporophyte fronds and the height of the longest frond were measured in a 60-day interval. The first measures were recorded after 283 days of cultivation (Time $1, \mathrm{~T}_{1}$ ) and the second measures after 343 days of cultivation (Time 2, $\mathrm{T}_{2}$ ). The relative growth rate (RGR) was estimated as ( $\mathrm{Log}$ $\left.\mathrm{L}_{2}-\log \mathrm{L}_{1}\right) / \mathrm{T}_{2}-\mathrm{T}_{1}$ where $\log$ is the natural logarithm, $\mathrm{L}_{2}$ is the length of the longest leaf at time 2 and $L_{1}$ is the length of the longest leaf when the sporophytes were transplanted into the pots, according to Bernabe et al. (1999).

Averages and standard deviation were calculated. The Kolmogorov-Smirnov test (Dmax) for normality was applied before analysis of variance, both for growth analysis and germinability data. The KolmogorovSmirnov test and the F test of Snedecor for the homogeneity of variance $(0.05)$ were both applied for germinability data before the analysis of variance. The Kolmogorov-Smirnov test showed absence of normality for the germinability in different temperatures and the Bartlett's test showed that the variances were not homogeneous for the germinability in different light levels, which were submitted to arcsine transformation. The same tests were applied again to the transformed data. After this procedure, the $\mathrm{pH}$ data showed normality and homogeneity of variance and the pairwise comparison was analyzed by the parametric Tukey Test (5\%). For the temperate and light levels data, that did not show normality or homogeneity of variance after angular transformation, the pairwise comparison was analyzed by the nonparametric Kruskal-Wallis Test $(H)$ followed by the Dunn test. Averages of fronds number and the length of the longest frond between $\mathrm{T} 1$ and $\mathrm{T} 2$, that did not show normality or homogeneity of variance, were also analyzed through the Kruskal-Wallis Test followed by the Dunn Test (Santana \& Ranal 2004; Zar1996). Statistical tests were performed through the Excel for Windows (Microsoft), Minitab for Windows and Biostat softwares (Microsoft).

\section{Results And Discussion}

When fern spores are cultivated in laboratory, they need to be superficially sterilized before being sowed in mineral solutions. Camloh $(1993,1999)$ reported the best germination of Platycerium bifurcatum (Cav.) C. Chr. (Polypodiaceae) with unsterilized spores, but contamination always occurred after 10 days of culture, which was the reason for the lower cell number as compared to sterilized spores. Simabukuro et al. (1998) comment that before the germination of drystored spores, in order to avoid the incidence of fungal growth, there is the need to sterilize them. In this work, spores of P. lepidopteris were surface sterilized in order to guarantee gametophyte development without contamination.

The $\mathrm{pH}$ range from 4.0 to $6.7 \mathrm{did}$ not affect the germination of $P$. lepidopteris spores after 28 days of inoculation (Fig. 1a). So, P. lepidopteris spores show plasticity concerning the $\mathrm{pH}$ factor. These data are in accordance with Millër (1968), who observed the highest percentages of germination for several fern species in acidic or neutral $\mathrm{pH}$. Nondorf et al. (2003) working with Cheilanthes feei Moore 
(Pteridaceae) spores, a xerophyte fern, observed that spores germinated at the highest rate in acidic $\mathrm{pH}(4.5$ and 5.5$)$, but the germination occurred in a broad $\mathrm{pH}$ range $(4.5$, 5.5, 6.0 and 8.5). However, some fern spores are not able to germinate in strong acidic conditions or the germinability is very low in such situations (Mohr 1956; Hevly 1963). In other species, a moderate germination
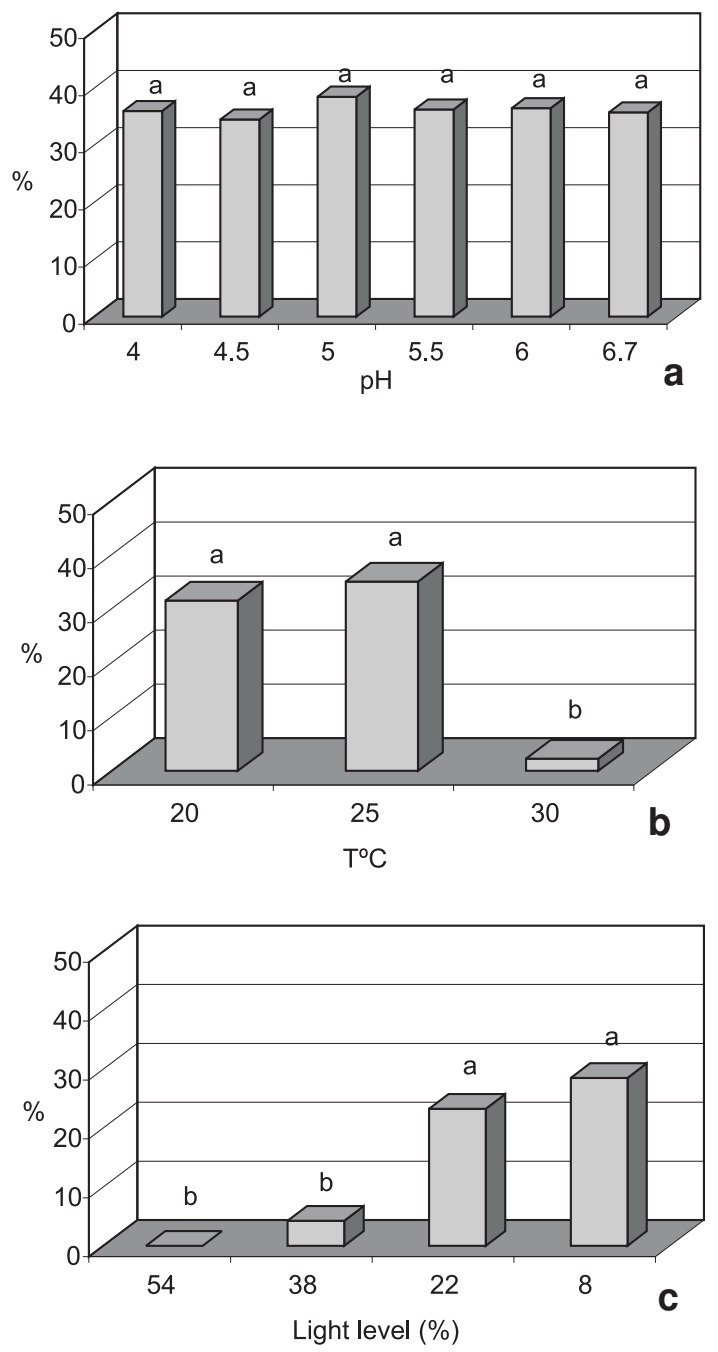

Figure 1 - Effects of $\mathrm{pH}$, temperature and light levels on the germination rate (\%) of Polypodium lepidopteris spores after 28 days of inoculation. Letters denote statistical differences. $*$ Data did not show normality. a. $\mathrm{pH} ; D=0.084 ; c^{2}=3.975 ; F=0.6261$

b. $\mathrm{T}^{\circ} \mathrm{C} ; D_{\max }=0.204^{*} ; c^{2}=4.092 ; H=8.5781$ (s)

c. Light levels; $D_{\max }=0.243 * c^{2}=12.837 * ; H=13.810$ (s) percentage is observed in acidic $\mathrm{pH}$, but the gametophyte development is quite limited (Courbet 1955; Otto et al. 1984). Spores from terrestrial species of Ophioglossaceae also show the highest germinability in slight acidic $\mathrm{pH}$ (Whittier 1981). Ophioglossum palmatum L. spores reached the highest germinability in strong acidic medium, but the germinability was reduced in less acidic or neutral conditions. (Whittier \& Moyroud 1993).

The germination of $P$. lepidopteris spores after 28 days of spore inoculation did not differ between 20 and $25^{\circ} \mathrm{C}$, but it was drastically inhibited at $30^{\circ} \mathrm{C}$ (Fig.1b). Data from literature also show similar responses for several fern species. Pérez-García \& Riba (1982) studied the effect of temperature on several species of Cyatheaceae and Dicksoniaceae: Cyathea fulva (Mart.\& Gal.) Fée, Lophosoria quadripinnata (Gmel.) C. Chr, Nephelea mexicana (Schl. \& Cham.) Tryon, Trichipteris bicrenata (Liebm) Tryon, Trichipteris scabriuscula (Maxon) Tryon and also observed partial inhibition of germination above $25^{\circ} \mathrm{C}$. Ranal (1999) studied the effect of temperature on several fern species from the Atlantic Forest of the state of São Paulo, Brazil, and observed similar germinability at all temperatures tested for Polypodium hirsutissimum Raddi, Polypodium latipes (L.) Watt. and Pteris denticulata Sw. (Polypodiaceae) but high germinability was observed between 18 and $25^{\circ} \mathrm{C}$ for Microgramma lindbergii (Kuhn) Sota, Microgramma squamulosa (Kaulf.) Sota and Polypodium polypodioides (L.) Watt. (Polypodiaceae). For Adiantopsis radiata (L) Fée (Pteridaceae) and Polypodium pleopeltifolium Raddi (Polypodiaceae) high germinability was verified at 21 to $29^{\circ} \mathrm{C}$. For spores of Rumohra adiantiformis (Forst.) Ching (Dryopteridaceae) Brum \& Randi (2002) observed high percentages of germination at 15,20 and $25 \pm 1^{\circ} \mathrm{C}$ but germinability was partially inhibited at $30 \pm 1^{\circ} \mathrm{C}$. Cheilanthes feei spores also germinated optimally at $25^{\circ} \mathrm{C}$ (Nondorf et al. 2003). Therefore, data from 
literature are similar to those observed for $P$. lepidopteris, with respect to the temperature required for germination. Raghavan (1989) explains that high temperatures uncouple the phytochrome during fern germination. Haupt (1991, 1992) observes that the phytochromemediated spore germination in Dryopteris filixmas L. and D. paleacea (Dryopteridaceae) is inhibited by raising the temperature from 22 to 27 or $32^{\circ} \mathrm{C}$. The elevated temperature is effective during the 'coupling phase' when the far-red phytochrome (Pfr) starts the processes leading to germination (Haupt 1990). It is generally accepted that Pfr starts a whole cascade of events, eventually culminating in gene-dependent protein synthesis as the immediate cause of the terminal response (Haupt 1992).

High percentages of germination of $P$. lepidopteris spores were observed at 8 and $22 \%$ of natural light and the germination was photoinhibited at 38 and $54 \%$ of light (Fig. 1c). A degradation of storage substances was also observed in spores, which were kept under $58 \%$ of light. On the other hand, under $8 \%$ of light and after 28 days of spore inoculation, laminar gametophytes were observed. The behavior of $P$. lepidopteris spores to light levels seems to be very usual for several fern species, which also presented optimal
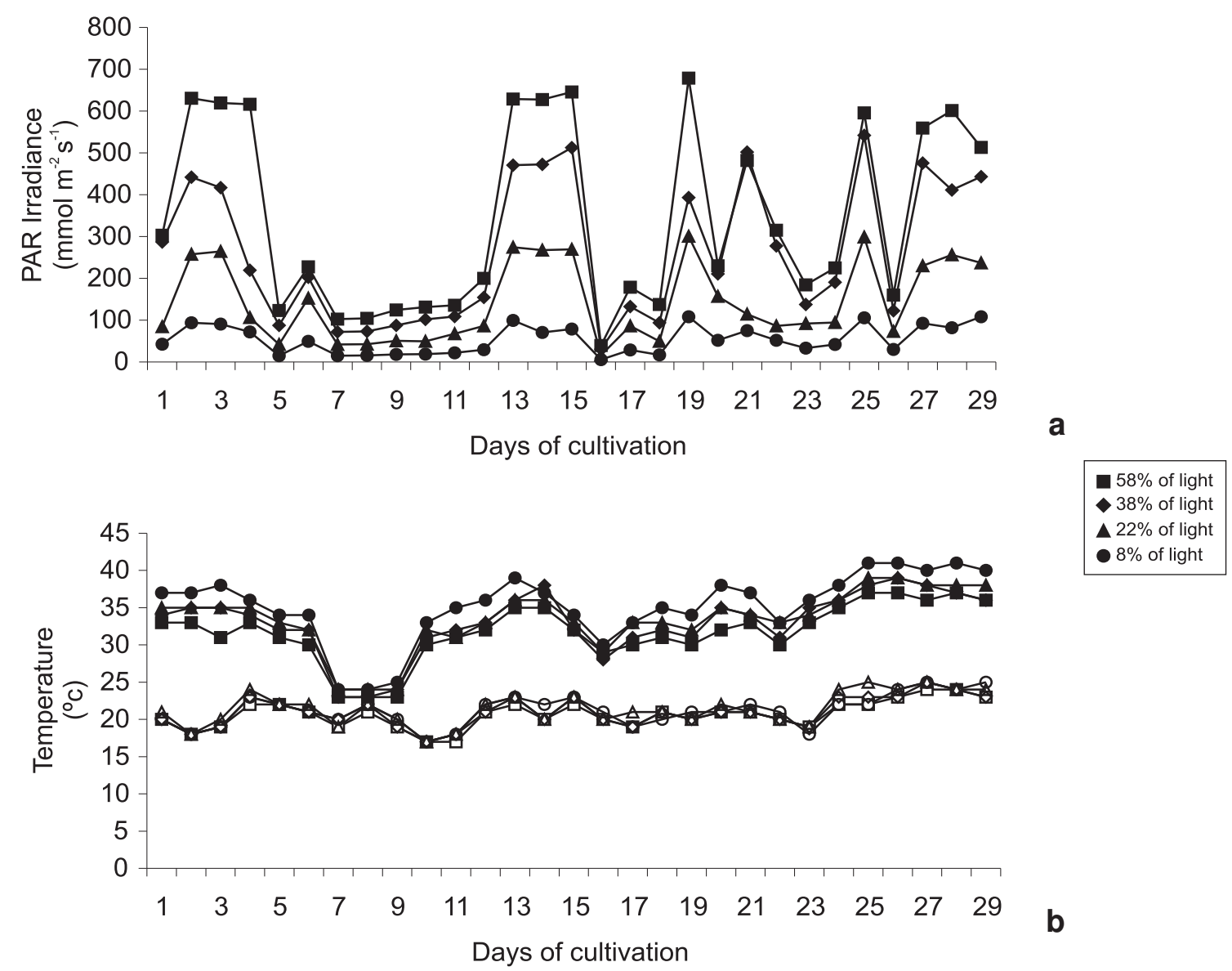

Figure 2 - Irradiances $\left(\mathrm{mmol} \mathrm{m} \mathrm{m}^{-2} \mathrm{~s}^{-1}\right)$ and minimal and maximum temperatures from November $21^{\text {st }}$ to December $19^{\text {th }}$ measured at noon inside the boxes of black shade where spores received different light levels. Open symbols are minimum temperatures and dark symbols are maximum temperatures. 
germinability at lower light levels. Filippini et al. (1999) and Renner \& Randi (2004) observed the highest germination percentages at 5 and $20 \%$ of light for spores of Dicksonia sellowiana Hook. (Dicksoniaceae). Brum \& Randi (2002) demonstrated that for $R$. adiantiformis spores, the highest germination percentages were achieved at 9 and $17 \%$ of light in April and August. Hiendlmayer \& Randi (2007) also found the best germinability for Cyathea delgadii Sternb. (Cyatheaceae) and Blechnum brasiliense Desv. (Blechnaceae) spores at 5 and $22 \%$ of light in April and July. These authors also observed gametophyte death of both species at 62 and $42 \%$ of light, after a few days of cultivation. This effect was probably a consequence of chlorophyll oxidation at higher light levels, which reduces the photosynthetic efficiency, limiting the plant growth and eventually causing plant death (Demming-Adans \& Adams 1992; Kitao et al. 2000). On the other hand, for Cheilanthes feei Moore, high germination rates were achieved under a regime of continuous light of $100 \mathrm{mmol} \mathrm{m}^{-2} \mathrm{~s}^{-1}$; however, this species can germinate under a wide variety of conditions including constant darkness (Nondorf et al. 2003). The irradiance from November $21^{\text {st }}$ to December $19^{\text {th }} 2006$ ranged from 39.5 to 678.8 mmol m $\mathrm{m}^{-2} \mathrm{~s}^{-1}$ at $54 \%$ of light. At $38 \%$ of light, it ranged from 30.4 to $541.6 \mathrm{mmol} \mathrm{m}^{-2} \mathrm{~s}^{-1}$. At $22 \%$ of light it ranged from 16.2 to $300.0 \mathrm{mmol}$ $\mathrm{m}^{-2} \mathrm{~s}^{-1}$ and at $8 \%$ of light it ranged from 5.6 to $107.9 \mathrm{mmol} \mathrm{m}^{-2} \mathrm{~s}^{-1}$ (Fig. 2a). Maximum temperatures ranged from $32^{\circ} \mathrm{C}(54 \%$ of light $)$ to $35^{\circ} \mathrm{C}$ ( $8 \%$ of light), but the minimum temperature average was constant $\left(21^{\circ} \mathrm{C}\right)$ inside the four 'sombrite' boxes (Fig. 2b). On windy days, higher temperatures were observed inside the $8 \%$ light box and lower temperatures inside the $54 \%$ light box which was more ventilated due to the larger holes in the black shade netting. The highest temperatures in the hotter days in the 8 and 22\% light boxes did not inhibit the germination of $P$. lepidopteris spores, that reached the highest percentages at the same light levels. On the other hand, the germination of $P$. lepidopteris was drastically inhibited at constant $30^{\circ} \mathrm{C}$. Probably, the daily day - night temperature oscillation and the low light intensity seem to be beneficial for the germination of $P$. lepidopteris spores.

Nondorf et al. (2003) reported that optimal conditions for spore germination are often a reflection of optimal growth conditions for the entire fern life cycles. Considering that $P$. lepidopteris grows in coastal dunes, where light incidence is intense and mineral nutrition and water are limiting factors, the spore germination photoinhition by high light intensity seems to be a paradox. It is possible that in its habitat, spores will only be able to germinate during rainy periods, in shady areas, with moderate temperatures and with some water retention in the soil pores in order to make gametophyte development and sporophyte formation possible. On the other hand, $P$. lepidopteris spores can germinate in broad $\mathrm{pH}$ ranges, showing plasticity to this requirement.

Table 1 - Frond number (FN) and height of the longest frond (FH) of Polypodium. lepidopteris sporophytes that grew in growth room at $25 \pm 2^{\circ} \mathrm{C}\left(22 \mathrm{mmol} \mathrm{m}^{-2} \mathrm{~s}^{-1}\right)$ under a 16 hour photoperiod. $\mathrm{T} 1=283$ days after spore inoculation; T2 = 343 days after spore inoculation. Letters denote statistical differences. * Data did not show homogeneity of variances.

\begin{tabular}{lll}
\hline & \multicolumn{1}{c}{ T1 } & T2 \\
& \multicolumn{2}{c}{$($ Mean \pm ic $)$} \\
\hline FN & $5.00 \pm 0.13 \mathrm{a}$ & $7.67 \pm 0.22 \mathrm{~b}$ \\
$D_{\max }$ & 0.046 & 0.047 \\
$F$ & & $2.842^{*}$ \\
$H$ & & 28.93 \\
FH $(\mathrm{cm})$ & $4.04 \pm 0.09 \mathrm{a}$ & $8.65 \pm 0.34 \mathrm{~b}$ \\
$D_{\max }$ & 0.051 & 0.076 \\
$F$ & & $3.935^{*}$ \\
$H$ & & 34.05 \\
RGR & & $0.15 \pm 0.009$ \\
$\quad\left(\mathrm{~cm} \mathrm{~cm}^{-1}\right.$ month $\left.^{-1}.\right)$ & & \\
FN month $^{-1}$ & & $1.33 \pm 0.09$ \\
\hline
\end{tabular}


The gametophytic phase shows plasticity due to large fluctuations in light intensity, light quality and mineral nutrition. Sato \& Sakai (1981) observed that gametophytes of Vittaria lineata (L.) Smith and Vittaria graminifolia Kaulf (Vittariaceae) could survive in sites where sporophytes do not develop. Similar response was observed for Trichomanes speciosum Willd. (Hymenophyllaceae) (Makgomol \& Sheffield 2001). This different gametophyte and sporophyte distribution pattern reflects the wide ecologic tolerance between both generations (Johnson et al. 2000). It is possible that P. lepidopteris gametophytes and sporophytes also present different requirements for growth and establishment.

During this experiment, gametophytes were not able to grow in washed sand. In the substrate of mixed sand, humus and typic hapludult soil (1:1:1), the number of sporophyte fronds and the height of the longest frond after 283 days of spore inoculation (Time 1) and after 343 days of spore inoculation (Time 2) were statistically different. The RGR based on the height of the longest frond was $0.15 \mathrm{~cm} \mathrm{~cm}^{-1}$ month $^{-1}$ (Table 1). Similar results were found by Hiendlmayer \& Randi (2007) working with four fern species from the Atlantic forest: Blechnum brasiliense Desv. (Blechnaceae), Cyathea corcovadensis (Raddi) Domin and Cyathea delgadii Sternb. (Cyatheaceae), and Saccoloma inaequale (Kze.) Mett. (Dennstaedtiaceae). Young sporophytes of $P$. lepidopteris produced $1.33 \pm 0.09$ fronds per month (Table 1). These data are similar to the results found for Acrostichum danaeifolium (Pteridaceae) in the environment, which were $1.0 \pm 0.03$ to $1.3 \pm 0.04$ fronds per month (Mehltreter \& Palacios-Rios 2003; Mehltreter et al. 2003).

According to Zamith \& Scarano (2006) restinga is both a geomorphological and a botanical term. Plant communities experience a wide array of adverse environmental conditions, such as high and low temperatures, flooding, drought, constant wind, high salinity and lack of nutrients.
Thus, diversity, productivity and structural complexity are lower in these communities. The restinga ecosystem is therefore unique because it comprises a pool of species with high ecological plasticity, since they colonize, survive and grow in the dry, resource-poor restingas. Paradoxically, it has been shown that few restinga plants are capable of establishing via seeds on bare sand and, therefore, the structure and function of open restinga vegetation relies on a few pioneer nurse-plants that facilitate the arrival and establishment of a number of other species (Scarano 2002).

$P$. lepidopteris is found in seaside vegetation (restinga) therefore it could be supposed that its gametophytes are able to develop in salty sand which is poor in mineral nutrition and organic matter. However, in the present study, sporophytes grew very well in a substrate that is a mixture of typic hapludult soil, sand and humus, which certainly is more enriched in nutrients than sand dunes. Actually, in the present paper, gametophytes were not able to develop in washed sand. So, how can gametophytes develop in this very restrictive habitat? This is a very instigating question. Possibly, these gametophytes will be able to grow only in sites that offer adequate nutrition, for example, parts of the sand soil previously colonized by other species and enriched with organic matter and recycled mineral nutrients, which is in accordance to comments on Scarano (2002). This is a matter of future investigations.

This study has shown that it is feasible to cultivate plants of $P$. lepidopteris from spores. The limiting factors for spore germination in mineral solution observed in this study were the high light levels and temperature of $30^{\circ} \mathrm{C}$. For the establishment of sporophytes, which was performed in laboratory, it was observed that mineral nutrition and high humidity are important factors, because gametophytes did not develop in pure sand and therefore, sporophytes were not produced. Such information may be useful for management and conservation of $P$. lepidopteris. 


\section{ACKNOWLEDGEMENTS}

Daniela Viviani and Áurea Maria Randi would like to thank CNPq (Conselho Nacional de Desenvolvimento Científico e Tecnológico - National Council of Scientific and Technological Development-Brazil) respectively for the MS grant and Áurea Maria Randi thanks CNPq for the research grant (level 2).

\section{REFERENCES}

Ambrósio, S. T. \& Barros, I. C. L. 1997. Pteridófitas de uma área remanescente de floresta atlântica do estado de Pernambuco, Brasil. Acta Botanica Brasilica 11: 105-113.

Barros, I. C. L.; Silva, A. J. R. \& Silva, L. L. S. 1989. Levantamento florístico das pteridófitas ocorrentes na zona das caatingas do estado de Pernambuco, Brasil. Biologica Brasilica 1: 143-159.

Bernabe, N.; Williams-Linera, G. \& PalaciosRios, M. 1999. Tree ferns in the interior and at the edge of a Mexican cloud forest remant: spore germination and sporophyte survival and establishment. Biotropica 31: 83-88.

Brum, F. R. \& Randi, A. M. 2002. High irradiance and temperature inhibit the germination of spores of the fern Rumohra adiantiformis (Forst.) Ching (Dryopteridaceae). Revista Brasileira de Botânica 25: 391-396.

CECCA. 1997. Centro de Estudos, Cultura e Cidadania. Unidades de conservação e áreas protegidas da Ilha de Santa Catarina. Caracterização e legislação. Ed. Insular, Florianópolis, 160p.

Camloh, M. 1993. Spore germination and early gametophyte development of Platycerium bifurcatum. American Fern Journal 83(3): 79-85.

Camloh, M. 1999. Spore age and sterilization affect germination and early gametophyte development of Platycerium bifurcatum. American Fern Journal 89(2): 124-132.

CONAMA. 1999. Resolução 261, que trata dos estágios sucessionais de vegetação de restinga para o estado de Santa Catarina. CONAMA, 12p.
Courbet, H. 1955. Influence de la concentration ionique du milieu sur la germination des spores et la croissance des prothalles de Filicales en culture aseptique. Comptes rendus de l'Académie des Sciences 241: 441-443.

Demming-Adams, B. \& Adams, W. I. 1992. Photoprotection and other responses of plants to high light stress. Annual Review of Plant Physiology and Plant Molecular Biology 43: 599-626.

Dyer, A. F. 1979. The culture of fern gametophytes for experimental investigation. In: The experimental biology of ferns. Academic Press, London. Pp. 253-305.

Fernández, H.; Bertrand, A. M. \& SanchezTames, R. 1996. Influence of tissue culture conditions on apogamy in Dryopteris affinis sp. affinis. Plant Cell Tissue and Organ Culture 45: 93-97. 1997. Gemmation in cultured gametophytes of Osmunda regalis. Plant Cell Report 16: 358-362.

Filippini, E. C. P.; Duz, S. R. \& Randi, A. M. 1999. Light and storage in the germination of spores of Dicksonia selowiana (Presl.) Hook., Dicksoniaceae. Revista Brasileira de Botânica 22: 21-26.

Gazda, V.; Gomes-Carneiro, M. R.; Barbi, N. S. \& Paumgartten, F. J. R. 2006. Toxicological evaluation of an ethanolic extract from Chiococca alba roots. Journal of Ethnopharmacology 105: 187-195.

Haupt, W. 1990. Phytochrome-mediated fernspore germination: inhibition by elevated temperatures. Photochemical Photobiology 52: 57-9.

1991. Phytochrome-controlled fernspore germination: phase-specific modulation by elevated temperatures. Photochemical Photobiology 54: 811-818.

1992. Phytochrome-mediated fernspore germination: a temperature-sensitive phase in the transduction chain after action of Pfr. Journal of Plant Physiology 140: $575-81$.

Hevly, R. H. 1963 Adaptations of cheilanthoid ferns to desert environments. Journal of Arizona Academic Science 2: 164-175. 
Hiendlmayer, R. \& Randi, A. M. 2007. Response of spores and young gametophytes of Cyathea delgadii Sternb. (Cyatheaceae) and Blechnum brasiliense Desv. (Blechnaceae) to different light levels. Acta Botanica Brasilica. 21(4): 909-915.

Johnson, G. N.; Rumsey, F. J.; Headley, A. D. \& Sheffield, E. 2000. Adaptations to extreme low light in the fern Tricomanes speciosum Willd. (Hymenophyllaceae). New Phytologist 148: 423-431.

Kitao, M.; Lei, T. T.; Koike, T. T.; Tobita, H. \& Maruyama, Y. 2000. Susceptibility to photoinhibition of three deciduous broadleaf tree species with different successional traits raised under various light regimes. Plant Cell and Environment 23: 81-89.

Labiak, P. H. \& Prado, J. 1998. Pteridófitas epífitas da Reserva Volta Velha, Itapoá, Santa Catarina, Brasil. Boletim do Instituto de Botânica 11: 1-79.

Makgomol, K. \& Sheffield E. 2001. Gametophyte morphology and ultrastructure of the extremely deep shade fern, Trichomanes speciosum. New Phytologist 151:243-225.

Mehltreter, K. \& Palacios-Rios, M. 2003. Phenological studies of Acrostichum danaeifolium (Pteridaceae, Pteridophyta) at a mangrove site on the Gulf of Mexico. Journal of Tropical Ecolology 19: 155-162

Mehltreter, K.; Rojas, P. \&. Palacios-Rios, M. 2003. Moth larvae-damaged giant leatherfern Acrostichum danaeifolium as host for secondary colonization by ants. American Fern Journal 93: 49-55.

Millër, J. H. 1968. Fern gametophytes as experimental material. Botanical Review 34: 361-440.

Mohr, H. 1956. Die Abhängikeit des protonemawachstums und der protonemapolarität bei farnen von Licht. Planta 47: 127-158.

Nondorf, L. S.; Dooley A. M.; Palmieri, M. \& Swatzell, J. 2003. The effects of pH, temperature, light intensity, light quality, and moisture levels on spore germination in Cheilanthes feei of Southeast Missouri. American Fern Journal 93: 56-69.
Otto, E. T.; Crow, J. H \& Kirby, E. G. 1984. Effects of acidic growth conditions on spore germination and reproductive development in Dryopteris marginalis (L.). Annals of Botany 53: 439-442.

Pérez-García, B. \& Riba, R. 1982. Germinacion de esporas de Cyatheaceae bajo diversas temperaturas. Biotropica 14: 281-287.

Raghavan,V. 1989. Developmental biology of fern gametophytes. Cambridge University Press, Cambridge, 384p.

Ranal, M. A. 1999. Effects of temperature on spore germination in some fern species from semideciduous mesophytic forest. American Fern Journal 89: 149-158.

Renner, G. D. R. \& Randi, A. M. 2004. Effects of sucrose and irradiance on germination and early gametophyte growth of the endangered tree fern Dicksonia sellowiana (Presl.) Hook (Dicksoniaceae). Acta Botanica Brasilica 18(2): 375-380.

Santana, D. G. \& Ranal, M. A. 2004. Análise da germinação. Um enfoque estatístico. Ed. UNB, Brasília, 247p.

Sato, T. \& Sakai, A. 1981. Cold tolerance of gametophytes and sporophytes of some cool temperature ferns native to Hokkaido. Canadian Journal of Botany 59: 604-608.

Scarano, F. 2002. Structure, function and floristic relationships of plant communities in stressful habitats marginal to the Brazilian Atlantic Rainforest. Annals of Botany 90: 517-524.

Simabukuro, E. A.; Dyer, A. F. \& Felippe, G. M. 1998. The effect of sterilization and storage conditions on the viability of spores of Cyathea delgadii. American Fern Journal 88: 124-132.

Tryon, R. M. \& Tryon, A. F. 1982. Ferns and allied plants with special reference to tropical America. Springer-Verlag, New York, 857p.

Whittier, D. P. 1981. Spore germination and young gametophyte development of Botrychium and Ophioglossum in axenic culture. American Fern Journal 71: 13-19. \& Moyroud, R. 1993. The promotion of spore germination and gametophyte 
development in Ophioglossum palmatum by low pH. American Fern Journal 83: 41-46.

Zamith, L. R. \& Scarano, F. R. 2006. Restoration of a restinga sandy coastal plain in Brazil: survival and growth of planted woody species. Restoration Ecology 14: 87-94.

Zar, J. H. 1996. Biostatistical analysis. $3^{\text {rd }}$ ed. Prentice Hall, Upper Saddle River, 662p. 